\title{
STUDI KORELASI BEBERAPA FAKTOR YANG MEMPENGARUHI KEJADIAN DEMAM BERDARAH DENGUE DI KABUPATEN BANYUMAS TAHUN 2010-2015
}

\author{
Adi Septian ${ }^{1)}$, M. Choiroel Anwar ${ }^{2)}$, Marsum ${ }^{3)}$ \\ Jurusan Kesehatan Lingkungan, Politeknik Kesehatan Kemenkes Semarang, \\ Jl. Raya Baturaden KM 12 Purwokerto, Indonesia
}

\begin{abstract}
Abstrak
Latar Belakang Di Kabupaten Banyumas, sejak tahun 2000 sampai tahun 2014 kasus DBD terjadi peningkatan secara fluktuatif, kasus tertinggi terjadi pada tahun 2010 yaitu sebanyak 696 kasus. Pada tahun 2014 terjadi sebanyak 209 kasus, dan pada tahun 2015 sampai Bulan September ini telah terjadi sebanyak 221 kasus DBD, hal tersebut menunjukan adanya peningkatan yang signifikan. Tujuan penelitian untuk mengetahui ada atau tidaknya hubungan ikilim, kepatadan penduduk dan ketinggian daerah dengan kejadian DBD. Metode penelitian ini bersifat kuantitatif dengan desain studi ekologi untuk membuat gambaran atau deskripsi tentang suatu keadaan secara objektif. Hasil penelitian Hasil penelitian menunjukkan variabel yang memiliki hubungan adalah curah hujan dengan nilai $p$-value $=0,016$, kelembaban dengan nilai $p$-value $=0,000$, kecepatan angin dengan nilai $p$ value $=0,000$, kepadatan penduduk dengan $p$-value $=0,000$. Suhu udara dan ketinggian daerah merupakan variabel yang tidak memiliki hubungan yang signifikan tetapi berisiko. Simpulan penelitian ini bahwa faktor iklim dan kepadatan penduduk dapat menjadi faktor risiko terjadinya penyakit demam berdarah dengue. Faktor yang memiliki hubungan signifikan diantaranya curah hujan, kelembaban, kecepatan angin dan kepadatan penduduk.
\end{abstract}

Kata kunci $\quad$ : iklim, demam berdarah dengue, GIS, kesehatan lingkungan

\begin{abstract}
[CORRELATED STUDY ABOUT FACTORS THATINFLUENCE DENGUE FEVER CASE IN BANYUMAS REGENCY YEAR 2016]. In Banyumas Regency since 2000 until 2014 the cases of DBD increased in fluctuation, the highest case happened in 2010 there were 696 cases. In 2014 there were 209 cases, and 2015 until September there were 221 cases of DBD, those cases shows that there is significant of increasing. This research aims to find out if there is a correlation between climate, population density, the height of area and DBD case. This research is quantitative with ecology study design to make an image or description about a condition objectively. The result of this research shows that variables which have correlation are rainfall withp-value $=0,016$, humidity withp-value $=0,000$, air velocity withp-value $=0,000$, population velocity with $p$-value $=0,000$. Temperature and elevation place are variables which do not have significant correlation but still risky. The conclusion of this research is that the climate and population density factors can be the risk factors of dengue fever disease. The factors which have significant correlation are rainfall, humidity, air velocity, and population density.
\end{abstract}

Keywords : climate, dengue fever, GIS, environmental health

\section{PENDAHULUAN}

Di Kabupaten Banyumas sendiri, sejak tahun 2000 sampai tahun 2014 kasus DBD terjadi peningkatan secara fluktuatif, kasus tertinggi terjadi pada tahun 2010 yaitu sebanyak 696 (42,59/100.000 penduduk) kasus. Pada tahun 2014 terjadi sebanyak 209 (12.79/100.000 penduduk) kasus, dan pada tahun 2015 sampai Bulan September ini telah terjadi sebanyak 221 (13.52/100.000 penduduk) kasus DBD, hal tersebut menunjukan adanya peningkatan yang signifikan (Dinkes Kab. Banyumas 2015).

Wilayah geografis Indonesia yang beriklim tropis dengan suhu yang berkisar 26,0 - 29, $0^{\circ} \mathrm{C}$ dengan tiga bulan musim hujan pada Desember, Januari. Februari dan tiga bulan musim kemarau

1) Email : adiseptian56@gmail.com

2) Email : irul1960@yahoo.co.id

3) Email : marsumrahma@gmail.com pada Juni, Juli, Agustus dapat menjadi wilayah hiperendemik DBD. Kondisi tersebut diperparah oleh perkembangan wilayah perkotaan yang semakin kompleks dan perkembangan wilayah pedesaan menjadi kota yang menurunkan kualitas lingkungan hidup dan berdampak pada perluasan habitat nyamuk Aedes aegypti sebagai vektor penyakit DBD. Kecenderungan masyarakat beraktivitas di bidang ekonomi dan dampak gas emisi, berkorelasi dengan pergeseran curah hujan dan peningkatan suhu rata-rata di bumi yang diperkirakan naik 1 $3,5^{\circ} \mathrm{C}$. Perubahan komponen lingkungan tersebut akan berkorelasi pada berbagai spesies pada ekosistem dan pola penyebaran vektor serta virus penyakit, seperti DBD (Junghans Sitorus, 2003). 
Perubahan iklim akan berpengaruh terhadap media transmisi penyakit, karena vektor akan berkembangbiak optimum apabila suhu, curah hujan, kecepatan angin dan kelembaban tersedia dalam jumlah yang optimum untuk kehidupannya. Perubahan iklim menyebabkan peningkatan suhu udara dan curah hujan disuatu daerah. Dengan tidak adanya sistim drainase yang baik maka akan terbentuk genangan-genangan air yang sangat cocok untuk tempat perkembangbiakan nyamuk tersebut. Sementara dalam siklus hidup nyamuk tersebut sangat dipengaruhi oleh tersedianya air sebagai media berkembang biak dari telur menjadi nyamuk dewasa. Dalam aktifitas sehari-hari nyamuk memerlukan suhu yang cukup tinggi dan didukung oleh udara yang lembab (Paul E. Parham,2010:44).

Tujuan dari penelitian ini yaitu untuk mengetahui ada atau tidaknya hubungan antara faktor iklim (suhu, kelembaban, curah hujan, kecepatan angin), kepadatan penduduk dan ketinggian daerah.

\section{BAHAN DAN METODE}

Variabel bebas dalam penelitian ini adalah beberapa faktor di Kabupaten Banyumas yang meliputi suhu udara, curah hujan, kelembaban, dan kecepatan angin serta kepadatan penduduk dan ketinggian daerah, Variabel terikat dalam penelitian ini adalah kejadian demam berdarah dengue di Kabupaten Banyumas tahun 2010 - 2015. Penelitian ini bersifat kuantitatif dengan desain studi ekologi untuk membuat gambaran atau deskripsi tentang suatu keadaan secara objektif, dan untuk melihat hubungan suatu gejala dengan peristiwa yang mungkin akan timbul dengan munculnya gejala tersebut. Pada penelitian ini teknik pengambilan sampel yang digunakan adalah pengambilan sampel berdasarkan pertimbangan (Purposive sampling). Sampel penelitian ini ialah total populasi yaitu semua wilayah di Kabupaten Banyumas Tahun 2010 $-2015$

Teknik pengumpulan data yang digunakan dalam penelitian yang bersumber pada tulisan maka digunakan metode dokumentasi. Dokumentasi berasal dari kata dokumen yang berarti barangbarang tertulis (Suharsimi Arikunto,2006:158). Instrumen yang digunakan dalam penelitian ini adalah menggunakan pedoman dokumentasi. Metode dokumentasi dilakukan dengan mencari data mengenai hal atau variabel yang berupa catatan harian, transkip, buku, surat kabar, majalah, dokumen, peraturan-peraturan, notulen rapat, agenda dan sebagainya. Pengumpulan informasi, dilakukan dengan membuat catatan yang diperlukan berdasarkan pedoman dokumentasi yang telah direncanakan. Di samping menggunakan alat tulis dalam pelaksanaan metode dokumentasi ini, juga dibantu dengan data dalam bentuk soft copy dan checklist untuk memperkuat argumentasi.

\section{HASIL DAN PEMBAHASAN}

Hasil analisis data tahun didapatkan bahwa pada tahun 2010 rata-rata kejadian Demam Berdarah Dengue adalah sebanyak 58 dari jumlah penduduk sebanyak 1.553.902, nilai median 53,50 kejadian dengan standar deviasi 22,16 kejadian. Dengan IR sebesar 44,79 per 100.000 penduduk. Pada tahun ini merupakan kejadian demam berdarah dengue terbanyak sepanjang tahun 2010 - 2015.

Penurunan jumlah kejadian Demam Berdarah Dengue sangat tajam terjadi pada tahun 2011 dibandingkan dengan tahun sebelumnya yaitu tahun 2010. Terdapat sebanyak 201 kejadian di tahun 2011 dan mengalami penurunan sebanyak 495 kejadian. Hasil analisis data didapatkan bahwa pada tahun 2011 rata-rata kejadian Demam Berdarah Dengue adalah sebanyak 16,75 dari jumlah penduduk sebanyak 1.557.624, dengan incidence rate sebesar 12,90 per 100.000 penduduk, nilai median 5 kejadian dan standar deviasi 13,29 kejadian.

Kenaikan tertinggi terjadi pada tahun 2013 karena kejadian jumlah Demam Berdarah Dengue mengalami kenaikan hampir tiga kali lipat dengan jumlah kejadian pada tahun sebelumnya yaitu tahun 2012. Jumlah kejadian Demam Berdarah Dengue pada tahun 2013 adalah 543 dengan incidence rate sebesar 33,87 per 100.000 penduduk, rata-rata 45,25 kejadian dan nilai median 49 kejadian dengan standar deviasi 27,34 kejadian.

1. Suhu dengan kasus DBD.

Hasil uji keeratan hubungan antara suhu udara dengan kejadian Demam Berdarah Dengue menunjukkan nilar r sebesar 0,158, ini berarti suhu udara mempunyai kekuatan hubungan yang sangat lemah. Hasil uji statistik didapatkan $p=0,185$, hal ini berarti nilai $p$ lebih besar dari $\alpha(0,05)$, sehingga disimpulkan bahwa tidak ada hubungan yang bermakna antara kejadian Demam Berdarah Dengue dengan suhu udara di Kabupaten Banyumas tahun 20102015.

Angka kejadian demam berdarah dengue tertinggi yaitu 104 kejadian di bulan Maret tahun 2010 terjadi ketika suhu udara tercatat pada suhu 23,82C dan angka kejadian terendah yaitu 0 kejadian di bulan Oktober tahun 2011 terjadi pada suhu $23,42^{\circ} \mathrm{C}$. Suhu tertinggi di Kabupaten Banyumas selama periode tahun 2010-2015 terjadi pada bulan Oktober tahun 2015 dengan suhu $25,02^{\circ} \mathrm{C}$ dan angka kejadian sebanyak 11 kejadian. Sedangkan suhu terendah terjadi pada bulan Juli tahun 2012 dengan angka kejadian sebanyak 28 kejadian.

Ini membuktikan bahwa perubahan pada suhu udara selama periode tahun 2010 - 2015 tidak memberikan korelasi yang bermakna terhadap kejadian demam berdarah dengue. Nyamuk dapat bertahan hidup pada suhu rendah $\left(10^{\circ} \mathrm{C}\right)$, tetapi metabolismenya menurun atau bahkan terhenti bila suhunya turun sampai 
dibawah suhu kritis $4,5^{\circ} \mathrm{C}$. Pada suhu yang lebih tinggi dari $35^{\circ} \mathrm{C}$ juga mengalami perubahan dalam arti lebih lambatnya proses-proses fisiologis, rata-rata suhu optimum untuk pertumbuhan nyamuk adalah $25-30^{\circ} \mathrm{C}$. Suhu udara mempengaruhi perkembangan virus dalam tubuh nyamuk, tingkat menggigit, istirahat dan perilaku kawin, penyebaran dan durasi siklus gonotrophik (Widya Hary Cahyati,2006;45)

Hal ini tidak sejalan sejalan dengan penelitian Junghans Sitorus (2003) di Kotamadya Jakarta Timur tahun 1998-2002 yang menyatakan bahwa ada hubungan yang signifikan dan berkorelasi negatif.

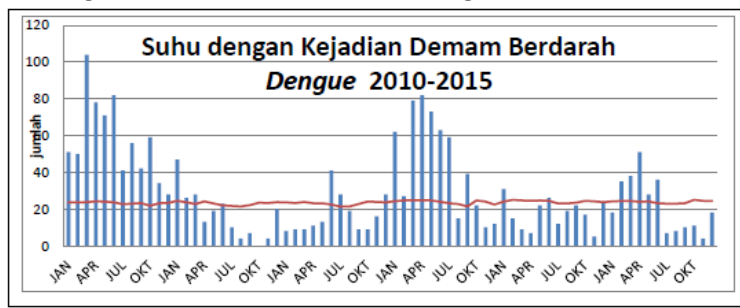

2. Curah Hujan dengan Kasus DBD

Hasil pengujian pada variabel curah hujan menunjukkan nilai r sebesar 0,283 yang berarti mempunyai kekuatan hubungan cukup dan berpola positif yang artinya jumlah kejadian Demam Berdarah Dengue akan meningkat bila curah hujan meningkat. Nilai signifikan atau $\mathrm{p}=$ 0,016 sehingga dapat disimpulkan bahwa ada hubungan bermakna antara curah hujan selama periode tahun 2010-2015 dengan kejadian demam berdarah dengue karena nilai p lebih kecil dari $\alpha(0,5)$.

Angka kejadian demam berdarah dengue tertinggi yaitu 104 kejadian di bulan Maret tahun 2010 terjadi ketika curah hujan tercatat sebesar $411 \mathrm{~mm}$ dan angka kejadian terendah yaitu 0 kejadian di bulan Oktober tahun 2011 terjadi pada curah hujan sebesar $155 \mathrm{~mm}$.

Curah hujan tertinggi di Kabupaten Banyumas selama periode tahun 2010-2015 terjadi pada bulan Desember tahun 2014 dengan curah hujan sebesar 729 mm dan angka kejadian sebanyak 24 kejadian. Sedangkan curah hujan terendah terjadi pada bulan September tahun 2011 dengan angka kejadian sebanyak 7 kejadian.

Hal ini membuktikan bahwa perubahan curah hujan selama tahun 2010 - 2015 memberikan korelasi yang bermakna terhadap kejadian demam berdarah dengue dengan tingkat hubungan cukup dan arah hubungan positif yaitu peningkatan curah hujan diikuti juga oleh peningkatan kejadian demam berdarah dengue begitu juga sebaliknya. Namun, kecenderungan ini tidak terjadi hampir di setiap kejadian, karena ada kecenderungan juga ketika curah hujan meningkat maka kejadian demam berdarah dengue menurun.

Hujan dapat mempengaruhi kehidupan nyamuk dengan 2 cara, yaitu: menyebabkan naiknya kelembaban nisbi udara dan menambah tempat perindukan. Setiap $1 \mathrm{~mm}$ curah hujan menambah kepadatan nyamuk 1 ekor, akan tetapi apabila curah hujan dalam seminggu sebesar $140 \mathrm{~mm}$, maka larva akan hanyut dan mati (Thomas Suroso,2010;1).

Hasil penelitian ini sejalan dengan penelitian Junghans Sitorus (2003) yang menyatakan bahwa terdapat hubungan yang signifikan antara curah hujan dengan kejadian demam berdarah dengue di Kotamadya Jakarta Timur tahun 1998 - 2002.

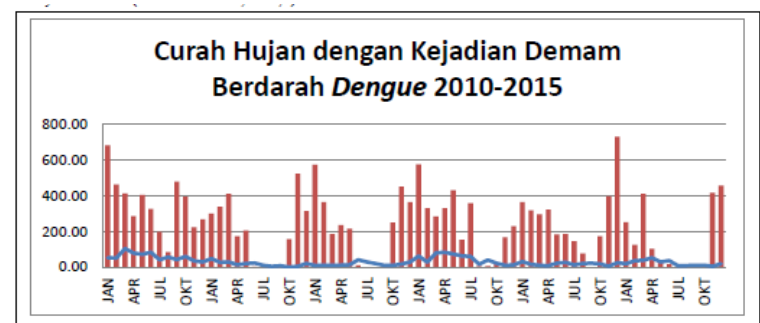

3. Kelembaban dengan Kasus DBD

Hasil uji keeratan hubungan antara kelembaban dengan kejadian Demam Berdarah Dengue menunjukkan nilar $\mathrm{r}$ sebesar 0,422, ini berarti kelembaban mempunyai kekuatan hubungan korelasi positif yang cukup, ini berarti kasus demam berdarah dengue berbanding lurus dengan kelembaban yang artinya saat kelembaban naik makan kasus demam berdarah dengue ikut baik. Hasil uji statistik didapatkan $\mathrm{p}=0,000$, hal ini berarti nilai $\mathrm{p}$ lebih besar dari $\alpha$ $(0,05)$, sehingga disimpulkan bahwa ada hubungan yang bermakna antara kejadian Demam Berdarah Dengue dengan kelembaban di Kabupaten Banyumas tahun 2010-2015.

Angka kejadian demam berdarah dengue tertinggi yaitu 104 kejadian di bulan Maret tahun 2010 terjadi ketika kelembaban tercatat sebesar 87,20\% dan angka kejadian terendah yaitu 0 kejadian di bulan Oktober tahun 2011 terjadi pada kelembaban 85,65\%.

Kelembaban tertinggi di Kabupaten Banyumas selama periode tahun 2010-2015 terjadi pada bulan November tahun 2011 dengan kelembaban 91,7\% dan angka kejadian sebanyak 4 kejadian. Sedangkan kelembaban terendah terjadi pada bulan Oktober tahun 2015 dengan angka kejadian sebanyak 11 kejadian.

Hal ini membuktikan bahwa perubahan kelembaban selama periode tahun 2010 - 2015 memberikan hubungan yang bermakna dengan tingkat hubungan cukup dan hubungan positif yaitu peningkatan kelembaban diikuti juga oleh peningkatan kejadian Demam Berdarah Dengue begitu pun sebaliknya. Namun, hal tersebut 
tidak sepenuhnya terjadi hampir di setiap kejadian dikarenakan ada kejadian dimana ketika kelembaban meningkat, kejadian Demam Berdarah Dengue menurun.

Sistem pernafasan nyamuk menggunakan pipa udara (trackea) dengan lubang-lubang pada dinding tubuh nyamuk (spiracle). Adanya spiracle yang terbuka lebar tanpa ada mekanisme pengaturannya. Pada saat kelembaban rendah menyebabkan penguapan air dari dalam tubuh sehingga menyebabkan keringnya cairan dalam tubuh. Salah satu musuh nyamuk adalah penguapan. Kelembaban mempengaruhi umur nyamuk, jarak terbang, kecepatan berkembangbiak, kebiasaan menggigit, istirahat, dan lain-lain (Widya Hary Cahyati,2006;46).

Penelitian ini sejalan dengan penelitian Ade Yuniarti (2009) yang menyatakan bahwa kejadian demam berdarah di Kota administrasi Jakarta Timur tahun 2004 - 2008 mempunyai hubungan yang signifikan dengan kelembaban. Penelitian lain yang sejalan yaitu penelitian dari Junghans Sitorus (2003) yang menyimpulkan bahwa kelembaban mempunyai hubungan yang kuat dan signifikan terhadap terjadinya kejadian Demam Berdarah Dengue di Kotamadya Jakarta Timur tahun 1998 - 2002.

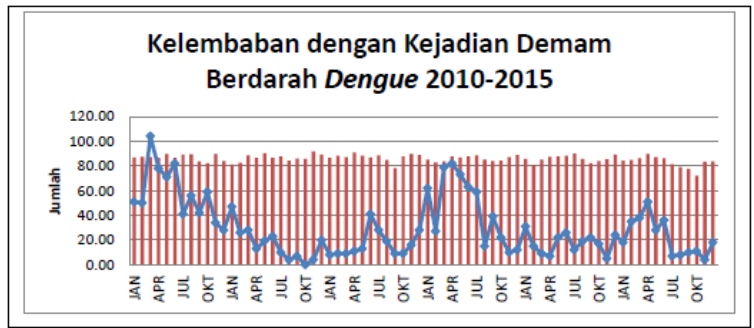

4. Curah Hujan dengan Kasus DBD

Hasil pengujian pada variabel kecepatan angin menunjukkan nilai $r$ sebesar -0.650 yang berarti mempunyai kekuatan hubungan kuat dan berpola negatif yang artinya jumlah kejadian Demam Berdarah Dengue akan meningkat bila kecepatan angin menurun. Nilai signifikan atau $p=0,000$ sehingga dapat disimpulkan bahwa ada hubungan bermakna antara kecepatan angin selama periode tahun 2010-2015 dengan kejadian demam berdarah dengue karena nilai $\mathrm{p}$ lebih kecil dari $\alpha(0,5)$.

Angka kejadian demam berdarah dengue tertinggi yaitu 104 kejadian di bulan Maret tahun 2010 terjadi ketika kecepatan angin tercatat sebesar $0 \mathrm{~km} / \mathrm{jam}$ dan angka kejadian terendah yaitu 0 kejadian di bulan Oktober tahun 2011 terjadi pada curah hujan sebesar $6.57 \mathrm{~km} / \mathrm{jam}$.

Kecepatan angn tertinggi di Kabupaten Banyumas selama periode tahun 2010-2015 terjadi pada bulan November tahun 2015 dengan curah hujan sebesar 7,22 km/jam dan angka kejadian sebanyak 4 kejadian. Sedangkan kecepatan angin terendah terjadi pada bulan maret tahun 2010 dengan angka kejadian sebanyak 104 kejadian.

Hasil penelitian ini tidak sejalan dengan penelitian Junghans Sitorus (2003) yang menyatakan bahwa tidak ada hubungan bermakna antara kecepatan angin dengan kejadian demam berdarah dengue di Kotamadya Jakarta timur tahun 1998 - 2002.

Angin dapat berpengaruh pada penerbangan dan penyebaran nyamuk. Bila kecepatan angin 11 - $14 \mathrm{~m} /$ detik atau 25 - $31 \mathrm{mil} / \mathrm{jam}$, akan menghambat penerbangan nyamuk. Kecepatan angin pada saat matahari terbit dan tenggelam yang merupakan saat terbang nyamuk ke dalam atau luar rumah, adalah salah satu faktor yang ikut menentukan jumlah kontak antara manusia dan nyamuk. Jarak terbang nyamuk (flight range) dapat diperpendek atau diperpanjang tergantung arah angin (Widya Hary Cahyati,2006;46).

Hasil yang tidak signifikan pada hubungan kecepatan angin dengan kejadian demam berdarah dengue pada penelitian ini, sehubungan dengan nyamuk Aedes aegypti adalah nyamuk dalam rumah sehingga hubungan kecepatan angin dalam penyebaran vektor ini sangat kecil. Selain itu, kecepatan angin di Kabupaten Banyumas yang relatif tetap dengan nilai tertinggi yaitu $5,77 \mathrm{~km} / \mathrm{jm}$ yang masih belum memenuhi batas kecepatan angin dalam menghambat perkembangan nyamuk.

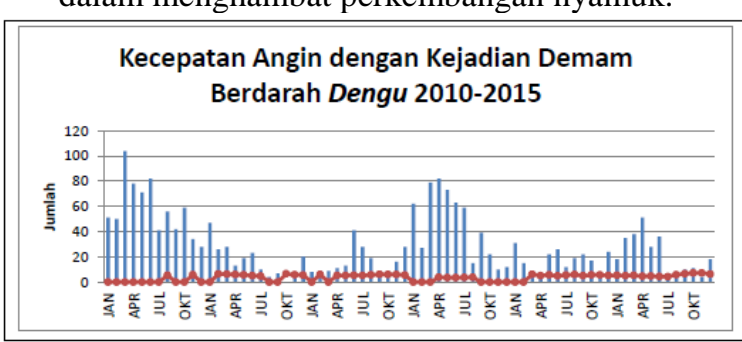

5. Kepadatan Penduduk Dengan Kasus DBD

Hasil pengujian pada variabel kepadatan penduduk menunjukkan nilai $r$ sebesar 0.637 yang berarti mempunyai kekuatan hubungan kuat dan berpola positif yang artinya jumlah kejadian Demam Berdarah Dengue akan meningkat bila kepadatan penduduk meningkat. Nilai signifikan atau $p=0,000$ sehingga dapat disimpulkan bahwa ada hubungan bermakna antara kepadatan penduduk selama periode tahun 2010-2015 dengan kejadian demam berdarah dengue karena nilai $\mathrm{p}$ lebih kecil dari $\alpha$ $(0,5)$.

Angka kejadian demam berdarah dengue tertinggi yaitu 123 kejadian di Kecamatan Purwokerto Selatan tahun 2010 terjadi ketika kepadatan tercatat sebesar 5.124 orang $/ \mathrm{km}^{2} \mathrm{j}$ dan angka kejadian terendah yaitu 0 kejadian di 
Kecamatan Tambak tahun 2011 terjadi pada kepadatan penduduk sebesar 806 orang $/ \mathrm{km}^{2}$.

Kepadatan penduduk tertinggi di Kabupaten Banyumas selama periode tahun 2010-2015 terjadi di Kecamatan Purwokerto Utara tahun 2014 dengan kepadatan penduduk mencapai 8.484 orang $/ \mathrm{km}^{2}$ dan angka kejadian sebanyak 23 kejadian. Sedangkan kepadatan penduduk terendah terjadi di Kecamatan Lumbir tahun 2010 dengan angka kejadian sebanyak 7 kejadian.

Suatu wilayah yang padat penduduknya menyebabkan populasi nyamuk Aedes aegypti meningkat, oleh karena itu kasus DBD lebih banyak ditemukan di daerah perkotaan yang padat penduduknya dan memiliki mobilitas tinggi. Berbeda dengan penyakit berbasis lingkungan lainnya, seperti malaria yang umumnya ditemukan di daerah pedesaan, dimana tempat perkembangbiakan nyamuk penyebab penyakit malaria adalah di daerah tergenangnya air yang langsung berhubungan dengan tanah seperti rawa, sedangkan vektor penyakit DBD berkembang biak pada tempat yang dapat menampung air bersih/jernih, seperti bak mandi, kaleng, botol, ban bekas dan lain sebagainya yang terdapat di lingkungan tempat tinggal.

Hasil penelitian Fitriyani (2007) dengan metode analisis dan pemetaan wilayah tingkat kerawanan BDB didapatkan bahwa wilayahwilayah yang termasuk dalam kategori sangat rawan dan rawan biasanya adalah ibukota kabupaten atau ibukota provinsi dengan tingkat kepadatan penduduk yang tinggi.

Penelitian Haryadi (2007) didapatkan bahwa kecamatan yang memiliki kepadatan penduduk yang tinggi berisiko 16 kali tertular DBD. Kemudian penelitian Hasyim (2009) terdapat hubungan antara kepadatan penduduk dengan kasus DBD dan berlangsung secara positif, artinya semakin tinggi kepadatan penduduk akan menyebabkan kemungkinan kasus DBD.

Keberadaan manusia secara langsung akan menarik berbagai energy. Manusia yang berkumpul akan membentuk suatu perubahan lingkungan. Pergerakan manusia dan intensitas pergerakan barang dan jasa akan mengakibatkan mudahnya penularan penyakit (Achmadi, 2011). Depkes RI (2007) mengatakan bahwa kepadatan penduduk merupakam faktor yang terkait dalam penularan DBD. Semakin padat, akan semakin mudah terjadi penularan DBD, karena jarak terbang nyamuk 50-100 meter. Menurut WHO (2010) pada area dengan kejenuhan manusia yang tinggi, banyak orang yang mungkin terpajan. Nyamuk akan mudah terinfeksi karena mengigit manusia yang dalam waktu viremia akan terinfeksi dan virus berkembang biak 8-10 hari.

Penularan virus dengue melalui gigitan nyamuk lebih banyak terjadi pada tempat yang padat penduduk seperti perkotaan dan perdesaan pinggir kota. Umumnya penduduk di pemukiman baru di pinggir kota berasal dari berbagai wilayah, oleh sebab itu di perlukan diantaranya terdapat penderita atau karier yang membawa tipe virus dengue yang berlainan dari masing-masing lokasi asal (Yatim, 2007). Penduduk yang padat akan berdampak pada mudahnya nyamuk dalam menginfeksi penduduk karena jarak tempuh terbang nyamuk untuk menggigit orang ke orang semakin kecil (Musabad,1997)

Tempat-tempat umum merupakan tempat berkumpulnya orang-orang yang dating dari berbagai wilayah, sehingga kemungkinan terjadinya pertukaran beberapa tipe virus dengue cukup besar (Depkes RI, 2007). Dalam penelitian Boewono, dkk (2012) menyatakan bahwa pola sebaran kasus DBD adalah mengelompok dan terkonsentrasi di pemukiman padat penduduk.

Faktor risiko dari kejadian penyakit selalu kompleks dan saling terkait. Pada dasarnya penyakit diakibatkan oleh lingkungan dan kependudukan (achmadi,2011). Intervensi yang tepat untuk mengatasi sebaran DBD ini tetap pada vektorya. Walaupun penduduk padat, namun jika vektor sedikit dan tidak infektif tentu penduduk tidak akan menjadi rentan (Depkes RI, 2007)

Apabila dilihat dari tahun ke tahun, terlihat kepadatan penduduk semakin meningkat namun kejadian DBD semakin menurun. Distribusi kejadian ini terlihat seperti hubungan dengan arah negatif antara kepadatan penduduk dan IR DBD. Hal ini mungkin disebabkan karena memang pola aktivitas epidemic DBD terjadi setiap 2-5 tahun.

Menurut WHO (2010) kejadian DBD memiliki dua pola epidemic pending. Pola umum kasus sporadic atau wabah kecil di area perkotaan yang ukurannya meningkat dengan tetap sampai terjadi wabah besar. Pola aktivitas epidemic ini akan terjadi setiap 2-5 tahun, sehingga setiap 5 tahun sekali DBD akan meningkat dan kemudian turun kembali. Oleh sebab itu Dinas Kesehatan Kabupaten Banyumas perlu melakukan siap siaga terhadap siklus 5 tahunan ini. Hendaknya masyarakat di berikan penyuluhan dan juga diajak untuk bersiap siaga terhadap siklus ini. 


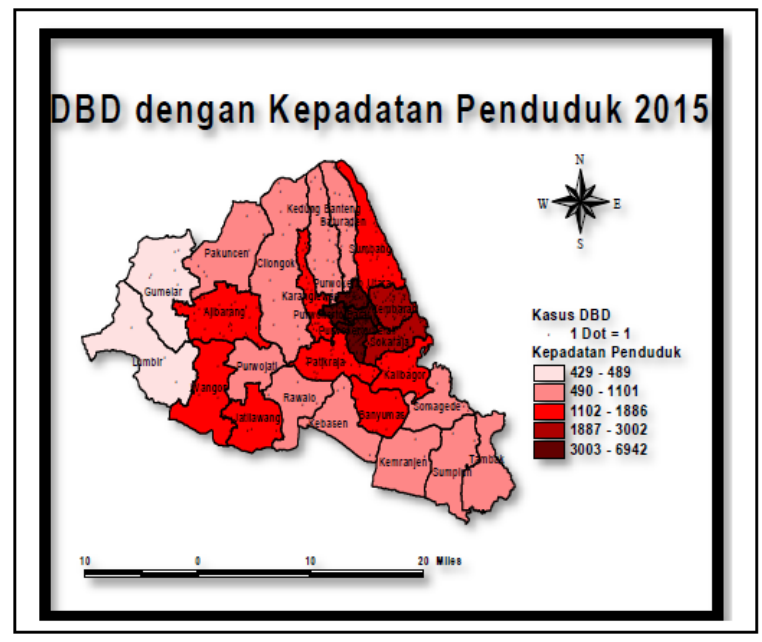

6. Ketinggian Daerah dengan Kasus DBD

Hasil pengujian pada variabel ketinggian daerah menunjukkan nilai $r$ sebesar -0.070 yang berarti mempunyai kekuatan hubungan negatif sangat lemah. Nilai signifikan atau $p=0,379$ sehingga dapat disimpulkan bahwa tidak ada hubungan bermakna antara selama periode tahun 2010-2015 ketinggian daerah dengan kejadian demam berdarah dengue karena nilai $\mathrm{p}$ lebih kecil dari $\alpha(0,5)$.

Angka kejadian demam berdarah dengue tertinggi yaitu 123 kejadian di Kecamatan Purwokerto Selatan tahun 2010 terjadi ketika ketinggian tecatat 74 MDPL dan angka kejadian terendah yaitu 0 kejadian di Kecamatan Tambak tahun 2011 terjadi pada ketinggian daerah sebesar 15 MDPL. Ketinggian daerah tertinggi di Kabupaten Banyumas selama periode tahun 2010-2015 adalah di Kecamatan Somagede dan Baturaden dengan ketinggian daerah mencapai 300 MDPL.

Kondisi lingkungan erat kaitannya dengan kehidupan manusia. Virus membutuhkan tempat dengan kondisi yang sesuai agar bias bertahan hidup dan menginfeksi pada host. Lingkungan fisik maupun non fisik memiliki sejumlah karakteristik tertentu yang dapat mempengaruhi kondisi perkembangan suatu penyakit (Fajriatin $\mathrm{W}, 2014)$.

Virus dengue dapat berkembang dengan baik berdasarkan kondidi wilayah tertentu. Penyakit DBD dapat menyebar pada semua tempat terkecuali tempat-tempat dengan ketinggian 1000 meter dari permukaan laut karena tempat yang tinggi dengan suhu yang rendah perkembangbiakan Aedes aegypti tidak sempurna (Fajriatin W, 2014).

Pengaruh variasi ketinggian berpengaruh terhadap syarat-syarat ekologis yang diperlukan oleh vektor penyakit. Di Indonesia nyamuk Ae. aegypti dan Aedes albopictus dapat hidup pada daerah dengan ketinggian 1000 meter diatas permukaan laut.
Semakin tinggi tempat maka suhu semakin rendah, kondisi ini menyebabkan perkembangan nyamuk Aedes aegypti semakin lambat sehingga penularan virus Dengue semakin kecil. Menurut Hidayati, dkk. (2012) pada tempat dengan elevasi lebih dari $1150 \mathrm{mdpl}$ peluang nyamuk menularkan virus sangat kecil dan pada tempat dengan elevasi lebih dari 1400 mdpl nyamuk tidak berkembang biak.

Sejalan dengan penelitian Rien Setianingsih tahun 2009 yang menyatakan bahwa tidak ada hubungan bermakna antara ketinggian daerah dengan kasus demam berdarah dengue.

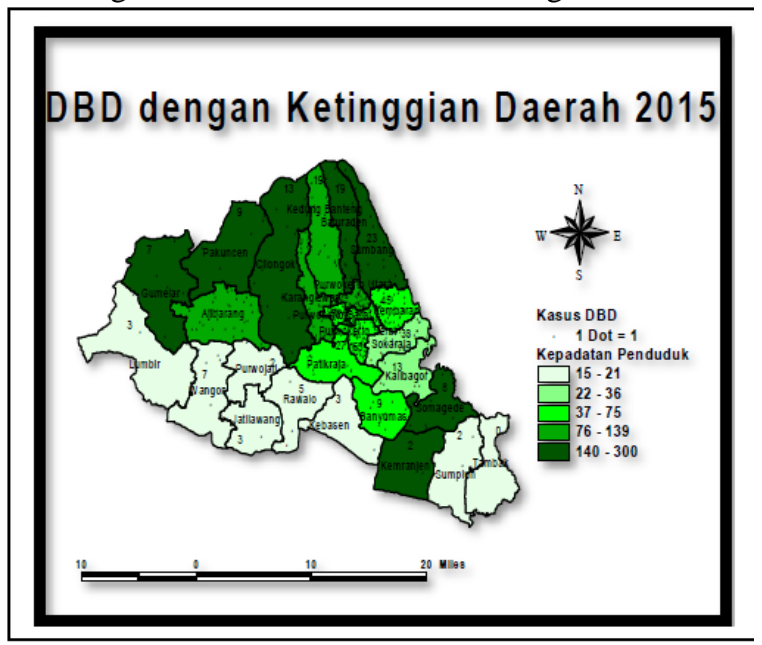

\section{SIMPULAN}

\section{Simpulan}

1. Kasus demam berdarah dengue di Kabupaten Banyumas tahun 2010-2015 paling tinggi terjadi pada tahun 2010 yaitu 696 kasus dengan IR sebesar 44,79 per 100.000 penduduk, sedangkan kasus paling rendah terjadi pada tahun 2012 sebanyak 200 kasus dengan IR sebesar 12,67 per 100.000 penduduk.

2. Tidak terdapat hubungan bermakna antara suhu udara dengan kejadian demam berdarah dengue di Kabupaten Banyumas tahun 2010-2015 $(\mathrm{p}=0.185 \mathrm{r}=0.158)$.

3. Terdapat hubungan bermakna cukup dengan arah positif antara curah hujan dengan kejadian demam berdarah dengue di Kabupaten Banyumas tahun 2010-2015 ( $\mathrm{p}=0.016 \mathrm{r}=0.283$ ).

4. Terdapat hubungan bermakna cukup dengan arah positif antara kelembaban dengan kejadian demam berdarah dengue di Kabupaten Banyumas tahun 2010-2015 ( $\mathrm{p}=0.000 \mathrm{r}=0.422$ ).

5. Terdapat hubungan bermakna kuat dengan arah negatif antara kecepatan angi dengan kejadian demam berdarah dengue di Kabupaten Banyumas tahun 2010-2015 ( $\mathrm{p}=0.000 \mathrm{r}=-0.650$ ).

6. Terdapat hubungan bermakna kuat dengan arah positif antara kepadatan penduduk dengan kejadian demam berdarah dengue di Kabupaten Banyumas tahun 2010-2015 ( $\mathrm{p}=0.000 \mathrm{r}=0.637)$. 
7. Tidak terdapat hubungan bermakna antara ketinggian daerah dengan kejadian demam berdarah dengue di Kabupaten Banyumas tahun 2010-2015 $(p=0.379 r=-0.070)$.

\section{Saran}

1. Kepada Badan Meteorologi Klimatologi dan Geofisika Kota Semarang

Diharapkan dari hasil penelitian ini dapat digunakan masukan sehingga dapat terjalin kerjasama antara BMKG kota semarang dengan instansi yang lainnya untuk bersama-sama berupaya menangani masalah Demam Berdarah Dengue. Adanya keterbukaan dalam penginformasian dan kerjasama yang baik, sehingga KLB penyakit DBD dapat diprediksi, dicegah, dan ditangani secara tepat.

2. Kepada Dinas Kesehatan Kabupaten Banyumas

a. Diharapkan hasil penelitian ini dapat digunakan sebagai bahan masukan bagi pengelola program Pencegahan dan Pemberantasan Penyakit khususnya sebagai pertimbangan dalam penentuan strategi pencegahan dan pemberantasan penyakit Demam Berdarah Dengue melalui kerjasama dengan Badan Meteorologi Klimatologi dan Geofisika Kota Semarang.

b. Diperlukan modifikasi lingkungan dengan mencanangkan suatu program penatalaksanaan lingkungan, seperti perbaikan sumplai dan penyimpanan air agar masyarakat tidak menampung air pada wadah-wadah yang besar.

3. Kepada Masyarakat Kabupaten Banyumas

Masyarakat ikut berpartisipasi dalam upaya pencegahan dengan cara tidak membiasakan diri dengan lingkungan yang lembab dan tidak meletakkan genangan air di tempat yang lembab karena mendukung pertumbuhan nyamuk, dan penanggulangan penyakit demam berdarah dengue dengan melaksanakan gerakan $3 \mathrm{M}+$ khususnya pada bulan basah atau penghujan serta menjaga imunitas dengan selalu meningkatkan kebugaran tubuh dengan olahraga, mengkonsumsi makanan bergizi, dan membiasakan perilaku hidup bersih dan sehat.

4. Kepada Peneliti Selanjutnya

Penelitian selanjutnya diharapkan menggunakan desain, sumber data, lokasi dan variabel yang berbeda. Penelitian disarankan tidak hanya menggunakan variabel suhu udara, curah hujan, kelembaban, dan kecepatan angin saja akan tetapi dengan variabel iklim lainnya yang diduga mempunyai hubungan dengan kejadian demam berdarah dengue. Data sekunder yang digunakan dalam penelitian selanjutnya disarankan menggunakan rentang waktu yang lebih panjang dari 6 tahun, misalnya 10 tahun.

\section{DAFTAR PUSTAKA}

Ade Yuniarti, 2009, Hubungan Iklim (Curah Hujan, Kelembaban dan suhu Udara) dengan Kejadian Penyakit Demam Berdarah Dengue (DBD) di Kota Administrasi Jakarta Timur tahun 2004-2008, Skripsi : Universitas Indonesia.

Achmadi, U. F, 2011, Dasar-dasar Penyakit Berbasis Lingkungan, Jakarta: PT Raja Grafindo Persada.

Angle M. H. Sorisi, 2013, Jurnal Biomedik Volume 5 Tahun 2013, Manado: Perhimpunan Ahli Anatomi Indonesia Komisariat Manado bekerjasama dengan Fakultas Kedokteran UNSRAT.

Aris Santjaka, 2011, Statistik Untuk Penelitian Kesehatan, Yogyakarta: Mulia Medika.

Arum Siwiendrayanti, 2007, Perubahan Iklim dan Pengaruhnya Terhadap Sektor Kesehatan, Volume 3, No 1, Juli 2007. Hlm 17-26.

Boewono, dkk., 2012, Distribusi Spasial Kasus Demam Berdarah Dengue, Analisis Indeks Jarak dan Alternatif Pengendalian Vektor di Kota Samarinda Provinsi Kalimantan Timur, Media Litbang Kesehatan Vol 22.

Clarisza Vietha Putri Dow, 2015, Hubungan Iklim Dengan Kejadian Demam Berdarah Dengue (DBD) di Kabupaten Pekalongan Tahun 2015, Proposal : Universitas Pekalongan.

Cut Meurah Regariana, 2004, Atmosfer (Cuaca dan Iklim), Solo: Tiga Serangkai.

Dantje T. Sembel, 2009 , Entomologi Kedokteran, Yogyakarta: CV Andi Offset.

Djoni Djunaedi, 2006, Demam Berdarah, Malang: UMM Press

Fitriyani, 2007, Penentuan Wilayah Rawan Demam Berdarah Dengue di Indonesia dan Analisis Pengatuh Polah Hujan Terhadap Tingkat Serangan, Skripsi.

Haryadi, Dedy, 2007, Analisis Spasial Penyakit Demam Berdarah Dengue (DBD) di Kabupaten Karawang tahun 2005-2007, Tesis: FKM UI

Hasyim, H, 2009, Analisis Spasial DBD di Provinsi Sumatera Selatan 2003-2007, Jurnal Kesehatan Indonesia. 
Hasyimi, M, 1999, Pengalaman Lapangan: Survei Jentik Nyamuk Penluar Demam Berdarah Dengue (DBD), Jurnal Epidemiologi Indonesia, volume 3 edisi 3

Hidayati, dkk., 2010, Dengue Early Warning model using Development Stages of Mosquito and Climate Information, BIOTROPIA, 19(1):31-41

Inge Sutanto dkk, 2008, Parasitologi Kedokteran, Jakarta: Balai Penerbit FKUI.

Junghans Sitorus, 2003, Hubungan Iklim dengan Kasus Penyakit Demam Berdarah Dengue (DBD) di Kotamadya Jakarta Timur Tahun 1998-2002 , Skripsi: Universitas Indonesia.

M. N. Bustan, 2002, Pengantar Epidemiologi, Jakarta: PT Rineka Cipta.
Musadad, A, 1997, Faktor-Faktor yang Berhubungan Dengan Insiden Demam Berdarah Dengue di Tingkat Kelurahan di Wilayah Jakarta Timur, Balitbangke Depkes RI.

Mustazahid Afgadi wirayoga, 2013, Hubungan Kejadian Demam Berdarah Dengue Dengan Iklim di Kota Semarang Tahun 2006-2011, Skirpsi : Universitas Negeri Semarang.

Nasrullah, 2009, Perubahan Iklim dan Trend, manado.kaukustujuhbelas.org/pdf, diakses pada tanggal 17 Oktober 2015 pukul 19.33 WIB.

Paul E. Parham, et al, 2010, Understanding and Modelling the Impact of Climate Change on Infectious Diseases-Progress and Future Challenges, 